\title{
Research on the Influencing Factors of College Students' Labor Education
}

\author{
Rong Chen, Fangjuan Xie* \\ Department of Physics, Nanchang Normal University, Nanchang, China \\ Email: *xiefangjuan@163.com
}

How to cite this paper: Chen, R. and Xie, F.J. (2020) Research on the Influencing Factors of College Students' Labor Education. Open Access Library Journal, 7: e7073.

https://doi.org/10.4236/oalib.1107073

Received: December 10, 2020

Accepted: December 25, 2020

Published: December 28, 2020

Copyright $\odot 2020$ by author(s) and Open Access Library Inc.

This work is licensed under the Creative Commons Attribution International License (CC BY 4.0).

http://creativecommons.org/licenses/by/4.0/

\begin{abstract}
Taking the students of Nanchang Normal University as the investigation objects, there is a significant correlation among labor consciousness, labor concept, labor skills and labor habits, and there is a strong positive correlation between them. Taking labor concept, labor skills and labor consciousness as independent variables and labor habits as dependent variables, a regression model is established to predict college students' labor habits, which provides support for colleges and universities to develop and cultivate college students' labor habits.
\end{abstract}

\section{Subject Areas}

Education

\section{Keywords}

College Students, Labor Education, Influencing Factors

\section{Introduction}

Nowadays, many college students do not pay attention to, are not keen on, or even accept labor education, which is directly related to the weakening of labor education for college students [1]. Remolding the status of labor education and enhancing the role of labor education in the education system are related to the historical burden of training socialist builders and successors in the new era. In today's social and economic environment, if we want to strengthen and improve the contemporary college students' cognition of the labor concept, we must establish a set of perfect labor education system.

1) The transformation of labor education form: Labor education is not limited 
to geographical location, but has been extended to cyberspace. Guo Zhang [2] (2020) elaborated that during the winter and summer vacation, facing the problems of college students' extended home time, excessive leisure time, excessive eye use, lack of exercise and other problems, the E-Class platform is used to carry out labor education for college students.

2) Labor education relies on project transformation. Labor education is not limited in the classroom, not limited in the experimental training room, labor education into social practice and innovation and entrepreneurship practice. Wang Ying and Wang Tao [3] (2020) deeply grasp the universality and uniqueness of labor education, on the basis of inheriting and carrying forward the excellent tradition of college students' labor education, actively explore effective ways to strengthen college students' labor education in the new era, and rely on the development of project-based social practice and innovation and entrepreneurship, in order to truly achieve the goal of cultivating new people of the times.

3) Labor education from qualitative analysis to quantitative analysis: By collecting and analyzing questionnaires, labor education has changed from qualitative analysis to quantitative analysis. Through the analysis of 761 questionnaires, Du Renjie and Gao Tian [4] (2020) have a relatively clear understanding of the current situation of college students' labor consciousness, aiming at the problems such as vague labor cognition, not yet establishing the concept of labor equality, which proposed to broaden school training channels, strengthen family labor education, and enhance subjective labor consciousness and so on.

This paper makes correlation analysis on the influencing factors of labor education, and constructs the influencing factor model, and presents the effectiveness of labor education in the way of quantitative prediction. According to the analysis results of these factors, we can get the path of implementing labor education, and train qualified socialist builders and successors for the society.

\section{Research Objects}

The research object of this paper is Nanchang Normal University students' views and attitudes towards labor education, and the implementation path and effectiveness of labor education.

1) The current situation of college students' labor education in the new era is summarized;

2) Chi square analysis of influencing factors of college students' labor education in the new era;

3) Pearson correlation analysis of labor education of college students in the new era;

4) The construction of the model among the influencing factors of college students' labor education in the new era;

5) The formulation and implementation of labor education program for college students in the new era and the evaluation of its effectiveness. 


\section{Main Contents}

In order to explore the relationship among college students' labor consciousness, labor habits and labor skills, construct the influencing factor model of labor education.

1) This paper analyzes the current situation, existing problems and main forms of labor education of college students through literature research.

2) Whether there is a direct relationship between labor consciousness and labor habits.

3) Whether there is a direct relationship between labor habits and labor skills.

4) This paper constructs the labor education model of college students, modifies the parameters of the model, and constructs the modified theoretical model.

5) According to the revised theoretical model of labor education, the training program of labor education for college students in the new era is formulated and implemented.

\section{Frequency Analysis}

This study takes the teacher of Nanchang Normal University as the investigation object, uses the questionnaire survey method to collect the sample data, collects data in the form of questionnaire which is self-designed on the basis of consulting a large number of literature and sends out the questionnaire through questionnaire star. 518 questionnaires were collected in the form of online questionnaires, all of which were valid. According to Table 1, 63.3\% of the respondents are male, $36.7 \%$ are female, $17.6 \%$ are only child, and $57.9 \%$ are rural, which shows that most of the students come from the countryside.

\section{Descriptive Analysis}

From Table 2, we can see that the mean value is between 2 and 3, which means that the satisfaction is between neutral and relatively satisfactory.

\section{Reliability Analysis}

It can be seen from Table 3 that the value of Cronbach's Alpha is 0.897 , so the coefficient is $>0.8$, which indicates that the reliability is very good.

Table 1. Frequency.

\begin{tabular}{cccc}
\hline Question & Option & Frequency & Percentage (\%) \\
\hline \multirow{2}{*}{ Sex } & Female & 190 & 36.7 \\
& Male & 328 & 63.3 \\
\multirow{2}{*}{ Only child } & Yes & 91 & 17.6 \\
& No & 427 & 82.4 \\
\multirow{2}{*}{ Hometown } & Countryside & 300 & 57.9 \\
& Town & 102 & 19.7 \\
& City & 116 & 22.4 \\
\hline
\end{tabular}


Table 2. Description statistics.

\begin{tabular}{cccccc}
\hline Variable name & $\begin{array}{c}\text { Sample } \\
\text { size }\end{array}$ & Minimum & Maximum & Mean & $\begin{array}{c}\text { Standard } \\
\text { Deviation }\end{array}$ \\
\hline Labor consciousness & 518 & 1.00 & 5.00 & 2.26 & 0.59 \\
Labour habits & 518 & 1.00 & 5.00 & 2.24 & 0.67 \\
Labor skills & 518 & 1.00 & 5.00 & 2.45 & 0.55 \\
Labor concept & 518 & 1.00 & 5.00 & 2.28 & 0.56 \\
\hline
\end{tabular}

Table 3. Reliability statistics.

\begin{tabular}{cc}
\hline Cronbach's Alpha & Number of Items \\
\hline 0.897 & 4 \\
\hline
\end{tabular}

\section{Validity Analysis}

From Table 4, KMO $>0.8$, which indicates that the validity is very good.

\section{Correlation Analysis}

It can be seen from Table 5 that there is a significant correlation among labor consciousness, labor concept, labor skills and labor habits, and the correlation coefficient is $>0.6$, indicating that there is a strong positive correlation between them.

\section{Regression Analysis}

Taking labor concept, labor skills and labor consciousness as input variables, taking labor habits as dependent variables and adopting input method, it can be seen from Table 6 and Table 7 that the established regression model has statistical significance, $R^{2}$ is 0.612 , indicating that the interpretation degree of the model is $61.2 \%$. The established model is shown in Table 8 .

$$
Y=-0.186+X_{1} * 0.209+X_{2} * 0.371+X_{3} * 0.456
$$

In the formula, $X_{1}$ for the labor consciousness, $X_{2}$ for the labor skills, $X_{3}$ for the labor concept, $Y$ for the labor habits. We can use Formula (1) to predict labor habits, and can take targeted measures to affect a factor or intervene in a factor, so as to affect the labor habits of college students.

\section{Conclusion}

By constructing the regression model of labor consciousness, labor concept and labor skills to labor habits, we can find the path to predict labor habits, formulate and implement labor education and training programs suitable for college students in the new era, so as to realize the purpose of "educating people by labor" and contribute to the socialist modernization construction. This paper only discusses the simple regression model, in-depth study needs to introduce a multi-level regression model, in order to measure from multiple perspectives. 
Table 4. KMO and Bartlett's test.

\begin{tabular}{lcc}
\hline \multicolumn{2}{c}{ Kaiser Meyer Olkin measure of sampling adequacy } & 0.926 \\
\hline & Approximate chi square & 5848.242 \\
Bartlett's sphericity test & df & 171 \\
& Sig. & 0.000 \\
\hline
\end{tabular}

Table 5. Correlation.

\begin{tabular}{ccccc}
\hline & labor consciousness & labor habits & labor skills & labor concept \\
\hline labor consciousness & 1 & & & \\
labor habits & $0.652^{\star *}$ & 1 & & \\
labor skills & $0.627^{\star *}$ & $0.694^{\star *}$ & 1 & \\
labor concept & $0.723^{\star *}$ & $0.734^{\star *}$ & $0.718^{\star *}$ & 1 \\
\hline
\end{tabular}

${ }^{* *}$ There is significant correlation at the level of 0.01 (bilateral), i.e., ${ }^{* *} \mathrm{p}<0.01$.

Table 6. Model summary.

\begin{tabular}{ccccc}
\hline Model & $\mathrm{R}$ & $\mathrm{R}^{2}$ & Adjust $\mathrm{R}^{2}$ & Error of standard estimation \\
\hline 1 & $0.782^{\mathrm{a}}$ & 0.612 & 0.610 & 0.41869 \\
\hline
\end{tabular}

Table 7. Anova ${ }^{\mathrm{b}}$.

\begin{tabular}{ccccccc}
\hline \multicolumn{1}{c}{ Model } & square sum & df & mean square & F & Sig. \\
\hline \multirow{3}{*}{1} & Regression & 142.160 & 3 & 47.387 & 270.311 & $0.000^{\mathrm{a}}$ \\
& residual & 90.106 & 514 & 0.175 & & \\
& total & 232.266 & 517 & & & \\
\hline
\end{tabular}

a. Predictive variables: (constant), labor concept, labor skills, labor consciousness; b. Dependent variable: labor habits.

Table 8. Coefficients ${ }^{\mathrm{a}}$.

\begin{tabular}{ccccccc}
\hline & \multicolumn{2}{c}{ Unstandardized Coefficients } & Standard coefficient & & Sig. \\
\cline { 2 - 5 } Model & $\mathrm{B}$ & Standard error & Beta & & \\
\hline (constant) & -0.186 & 0.089 & & -2.104 & 0.036 \\
$1 \quad$ labor consciousness & 0.209 & 0.046 & 0.185 & 4.527 & 0.000 \\
labor skills & 0.371 & 0.050 & 0.303 & 7.474 & 0.000 \\
labor concept & 0.456 & 0.054 & 0.383 & 8.397 & 0.000 \\
\hline
\end{tabular}

a. Dependent variable: labor habits.

\section{Acknowledgements}

Project supported by Training program for college students (Grant No. S202014437004, S202014437012, 201714437010, 201714437011, 201914437012, 201914437013) and also by the research on teaching reform of Nanchang Normal University (Grant No. JGKT-19-12). Labor education runs through the whole process of innovation and entrepreneurship, stimulates the spirit of the 
team to bear hardships, and is easy to carry out and complete the project.

\section{Conflicts of Interest}

The authors declare no conflicts of interest regarding the publication of this paper.

\section{References}

[1] Zou, D., Zhang, S. and Zhao, K. (2020) Analysis of the Significance and Countermeasures of Developing Students' Labor Education in Higher Vocational Colleges. Journal of Liaoning Higher Vocational, 22, 72-75.

[2] Zhang, G. (2020) How to Carry out College Students' Labor Education with the Help of the Internet during the Holidays: A Case Study of Yiban's Column “Taste of Eating Light". Science and Technology Perspective, 317, 65-67.

[3] Wang, Y. and Wang, T. (2020) Research on the Optimization of the Path of Labor Education for College Students. China Higher Education Research, No. 8, 67-70.

[4] Du, R.J. and Gao, T. (2020) Research on Current Situation and Cultivating Path of College Students' Labor Consciousness. Journal of Shenyang Jianzhu University (Social Science), 22, 82-86. 